\title{
A Male-sterile Cherry Tomato Breeding Line, NC 2C ms-10,aa
}

\author{
R.G. Gardner ${ }^{1}$ \\ Department of Horticultural Science, North Carolina State University, Raleigh, \\ NC 27695-7609
}

Additional index words. Lycopersicon esculentum, vegetable breeding, pollination

NC 2C $m s-10$, aa is a male-sterile version of the cherry tomato (Lycopersiconesculentum Mill.) breeding line NC 2C PVP (Gardner, 1993), developed by using the backcross breeding method, and is useful as a female parent to produce $\mathrm{F}_{1}$ hybrid seed.

\section{Origin}

NC 2C ms-10, aa was developed by transferring the $m s-10$ nuclear male-sterile gene

Received for publication 7 July 1999. Accepted for publication 5 Nov. 1999. The use of trade names in this publication does not imply endorsement by the North Carolina Agricultural Research Service (NCARS) of the products named, nor criticism of similar ones not mentioned. This research was funded by the NCARS and the North Carolina Tomato Growers Association. The cost of publishing this paper was defrayed in part by the payment of page charges. Under postal regulations, this paper therefore must be hereby marked advertisement solely to indicate this fact.

${ }^{1}$ E-mail address: Randy_Gardner@ncsu.edu and a linked seedling marker gene $a a$, anthocyanin absent, from 'Monalbo' $m s-10, a a$ (obtained from J. Philouze) into NC 2C PVP. The initial cross of a male-sterile cherry line, derived from earlier breeding involving 'Monalbo' $m s-10, a a$ and NY 402 cherry tomato, was made with NC 2C PVP as the male parent (Fig. 1). Following this cross, six backcrosses were made with NC 2C PVP as a recurrent male parent. Following the second and fifth backcrosses, six plants were selfpollinated and $\mathrm{F}_{2}$ segregants homozygous for $m s-10$ and $a a$ were selected for use as female parents for the next backcross. In addition, selection was made throughout the backcross program for fruit and plant type most closely resembling NC 2C PVP.

\section{Description}

In repeated trials of $\mathrm{NC} 2 \mathrm{C} \mathrm{PVP}$ and the backcross line NC 92110 (heterozygous for $m s-10, a a)$ in the greenhouse and field, no differences were detected in plant or fruit characteristics of the two lines. NC $2 \mathrm{C} \mathrm{ms}$ $10, a a$ has the same characteristics as previously described for NC 2C PVP (Gardner, 1993). Major plant and fruit characteristics controlled by single genes include determinate growth $(s p)$, uniform light green color of nonripe fruit $(u)$, and jointless pedicels $(j-2)$.

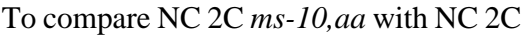
$\mathrm{PVP}$ in hybrid seed production, both were pollinated with pollen of NC 1C PVP to produce hybrid seed of 'Mountain Belle'. In replicated trials conducted during three growing seasons, the two hybrids did not differ in earlyor total-season yields. Fruit size tended to be slightly, but not significantly, smaller for the progeny of the male-sterile female parent. Observations of plant and fruit characteristics of the two hybrids in the replicated trials and in several other trial plots over a 3-year period indicated no visible differences for any character.

Use

The recessive $m s$ - 10 gene for male sterility in tomato is useful for producing hybrid seed because of its stability for sterility and reduced anther size, obviating the need for emasculation (Shakya and Scott, 1983). Since the $m s-10$ gene has to be carried in the heterozygous condition to be reproduced from seed, the linked seedling marker gene $a a$ for green stem (absence of anthocyanin in the seedling stem) is useful in identifying plants homozygous for the recessive $m s$ - 10 gene at the time seedlings emerge (Tanksley and Zamir, 1988). The $a a$ gene is 10 crossover units from $m s-10$ on chromosome 2 of tomato (Mutschler et al.,

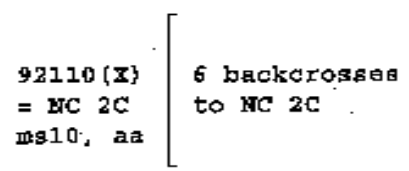

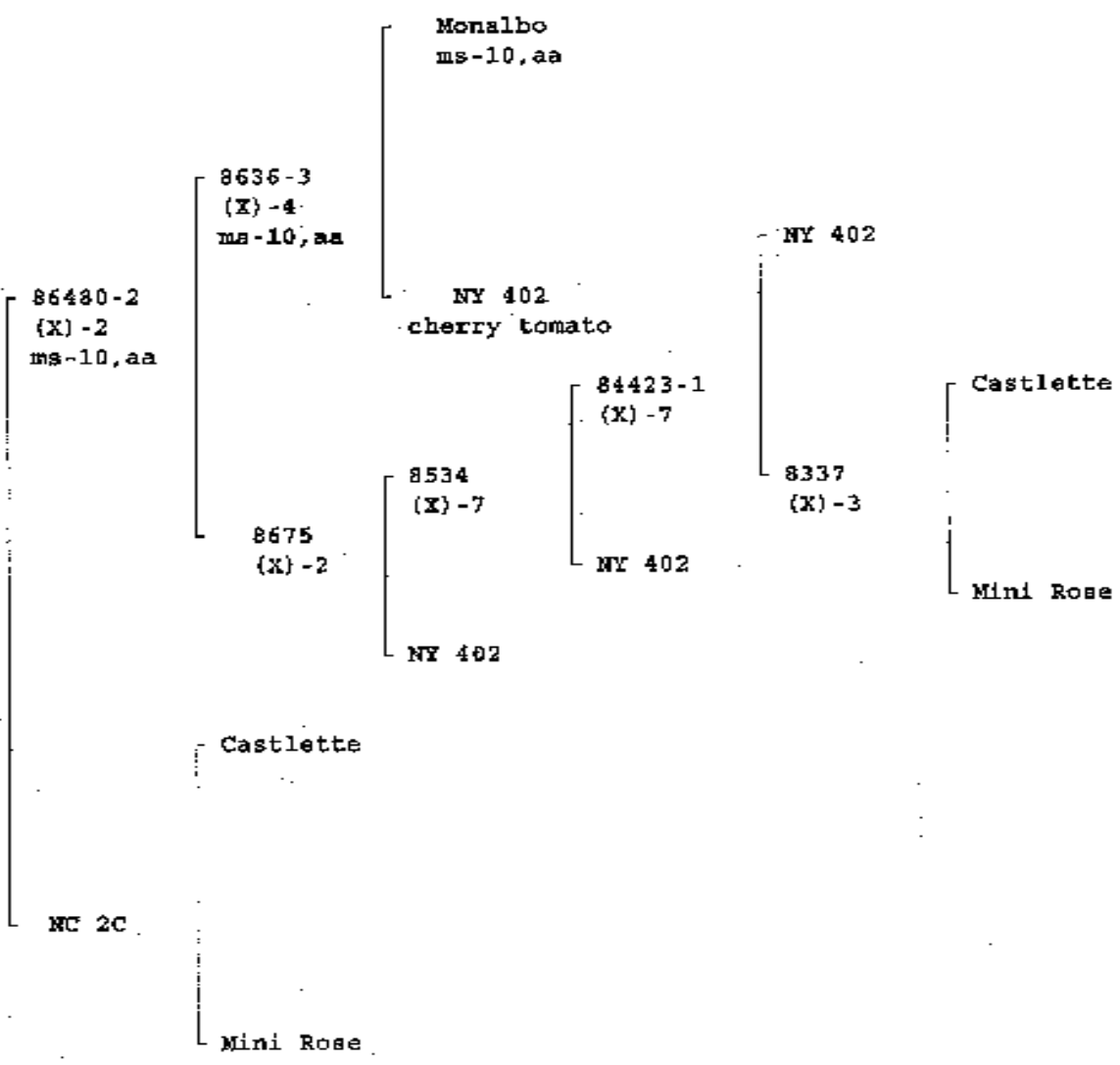

Fig. 1. Pedigree of NC 2C ms 10, a a male-sterile cherry tomato breeding line. 
1987). As a result, $90 \%$ of green-stemmed plants in an $\mathrm{F}_{2}$ population grown from selfs of $\mathrm{F}_{1}$ plants heterozygous for $m s-10$ and $a a$ are sterile and can be distinguished easily at flowering by the reduced anther size, exposed stigma, and lack of pollen.

NC $2 \mathrm{C} m s-10$, aa has been used experimentally several times in the greenhouse in production of hybrid seed. Eliminating the need for emasculation has reduced the labor required for seed production. In addition, flowers can be pollinated at the optimum stage, resulting in excellent seed set. Male-sterility is especially valuable in cherry tomatoes, which are difficult to emasculate because flowers are small, with thin, delicate styles that break easily during emasculation.

An additional advantage of using the $m s$ -
10 gene to facilitate hybrid seed production is the prevention of accidental selfing of the female parent. In hybrids made using emasculation of fertile female parents, extreme care must be taken to insure that self-pollination of the female parent does not occur. In thousands of plants grown from hybrids using an $m s-10$ male-sterile female parent, no indication of self-pollination of the female parent has been observed.

\section{Availability}

NC 2C $m s-10, a a$ is available as the $\mathrm{F}_{2}$ generation of the backcross line NC 92110 Seed of NC 2C ms-10, aa should be requested from R.G. Gardner, Mountain Horticultural Crops Research and Extension Center, 2016
Fanning Bridge Road, Fletcher, NC 287329244.

\section{Literature Cited}

Gardner, R.G. 1993. 'Mountain Belle' cherry tomato; $\mathrm{NC} 1 \mathrm{C}$ and $\mathrm{NC} 2 \mathrm{C}$ cherry tomato breeding lines. HortScience 28:349-350.

Mutschler, M.A., S.D. Tanksley, and C.M. Rick. 1987. 1987 linkage maps of the tomato (Lycopersicon esculentum). Rpt. Tomato Genet. Coop. 37:5-34

Shakya, J.M. and J.W. Scott. 1983. Influence of flower maturity and environment on hybrid and selfed seed production of several tomato genotypes. J. Amer. Soc. Hort. Sci. 108:875-878.

Tanksley, S.D. and D. Zamir. 1988. Double tagging of a male-sterile gene in tomato using a morphological and enzymatic marker gene. HortScience 23:387-388. 